\title{
Teaching Journalism at a Distance: The Case of the Zimbabwe Open University (ZOU) (Harare Regional Centre)
}

\author{
Elliott Muchena \\ Lecturer (Department of Media and Journalism Studies) Zimbabwe Open University, Box 8306, Harare, \\ Zimbabwe.
}

\begin{abstract}
The Zimbabwe Open University (ZOU) is the only Open and Distance Learning (ODL) institution set by government to cater for citizens who had been disadvantaged by different restrictions in the conventional university system. Journalism is a practice based course and this paper investigates how ZOU incorporates this teaching aspect. The key elements under investigation are students' satisfaction and course impact. Recently scholars have highlighted that ODL has been greatly appreciated since it has opened up the learning opportunities for many people. However, ODL institutions have often been found wanting in terms of practical tools required for certain media courses. This paper argues that such tools are essential to achieve the desired impact and student satisfaction. The study used the qualitative methodology and the case study approach adopted. The main instruments of data collection were the questionnaire and discussions. A total of 20 students and four part-time tutors participated in this research. Findings from this research showed that media students at ZOU are happy with this flexible and convenient learning model but some students bemoaned the lack of practical sessions. The study recommends that despite being an ODL institution ZOU must provide media students with practical laboratories for hands on practice and other contemporary media tools in order to achieve the necessary impact and student satisfaction.
\end{abstract}

Key words: Open and distance learning; media education; journalism practice.

\section{Introduction}

This paper is an analytical exposition of how the Zimbabwe Open University (ZOU) is teaching journalism using the Open and Distance teaching mode. It briefly looks at the colonial education system, its effects and how these were addressed from 1980 when Zimbabwe attained independence. The paper will then focus on how ZOU is operationalising the training of journalists and other media personnel through distance education. Finally, the paper emerges with possible practical suggestions on how the institution, with infrastructure challenges and shortage of other resources, may improve the training of journalists through open and distance learning.

\section{Research Objectives}

It is against this background that this paper seeks to investigate the following:

- Whether ZOU is effectively teaching journalism using the distance mode.

- Do practising journalists benefit from the ODL methods used at the University?

- Whether ZOU has other support mechanisms to facilitate learning.

\section{General Education during colonial period - A Brief Background}

The Rhodesian government before 1980 had educational policies that served the interests of the white male-dominated colonial social-economic system. According to Gordon (1994), the colonial education policies were race specific and the period witnessed two systems of education namely the European Division and the African Division. Although they had the resources, the European education sector which covered the whites, coloured and Asian children was a non-fee paying, compulsory and of higher quality whilst the African sector was neither free nor compulsory and had inadequate education provisions specifically for black children.

The colonial education system also used the bottle neck policy towards the black children. Only as little as $12.5 \%$ of all black children who had completed primary school were allowed to go for secondary education (the F1 schools) (Mlahleki, 1995). Such a low percentage was arrived at using very strict marking of the Standard 6 and Grade7 final examinations.

From the mid 1970's some vocational secondary schools (F2 schools) were introduced and these absorbed a further $37,5 \%$ of primary school graduates. From this the remaining $50 \%$ had to do other activities which totally had nothing to do with education or were expected to pursue their education through 
correspondence. Such policies led to the marginalisation of black children in the education systems (Mlahleki, 1995).

The patriarchal Zimbabwean society then also further marginalised the girl child. This was made worse by the promulgation of the customary law by the colonial government which made women wield very little if not no power in both civic and social circles.

With such scenario journalism training was not offered in the country since all media organisations were South African based. The profession was dominated by whites who were trained in South Africa. The blacks were only in media houses as messengers and doing other menial jobs and some "clever" blacks were later trained under the cadetship scheme as reporters. The present form of distance education (correspondence) started later and was offered initially by Colleges in South Africa.

\section{History of Journalism training in Zimbabwe}

Journalism training in Zimbabwe started during the colonial era. Since the first print media house was owned by the Argus Group of South Africa, the majority white reporters were trained in South Africa and moved to Zimbabwe formerly Rhodesia to take up employment.

The first training college to enrol students for journalism training was the Christian College of Southern Africa (CCOSA). CCOSA was founded and run by Dr Warner a white missionary. He opened the college initially to train African students in areas of religious studies, secretarial studies and journalism. These three areas have remained the dominant programmes offered by the college up to date.

Journalism training at Christian College of Southern Africa (CCOSA) started in 1976 and the majority of the crop of senior journalists in Zimbabwe today is products of this college. The programme is still running today and even popular because these senior journalists assist in publicising the college and encourage the young generation interested in the field to be trained at CCOSA. However, the depth of training, programme content and the experience of trainers have changed significantly.

An unfortunate development that weighed heavily on the institution was the movement of Dr Warner from Zimbabwe to America at the height of economic instability in the 1990s. This has led to some essential literature about journalism training disappear. The college is now being run by some of his appointees but the standards of training at the college have tremendously gone down.

Another development soon after independence in 1980 was the establishment of the Division of Mass Communication at the Harare Polytechnic College to train journalists. The school was sponsored by donors to quickly fill in the gap of trained white reporters who had fled the country upon attainment of black majority rule.

During this period the dominant training model of training journalism in most African countries was the short course type. These short-term courses were intensified after independence as a way of inculcating the patriotic journalism post-colonial governments wanted to see in the media. According to Hachten (1968) Zimbabwe like any other post-colonial African country wanted to see more Africans entering the journalism profession.

The Division of Mass Communication established by Government, like many such schools in Africa adopted an American style of journalism training which is seen as being more practical-oriented than the European or British model, which was too academic. Murphy and Scotton (1987) quoted in Skjerdal (2011) stated that even the journalism programme introduced by Kwame Nkrumah at the Ghana Institute of Journalism in 1958 was based on the American curricula. This could have been done also as a way of totally breaking away with the British colonial history. Jimanda (1992) also noted similar observation in Nigeria where the journalism training shifted from a British to an American style after independence.

The American influence is predominantly "visible in the names of many journalism schools in English speaking Sub-Saharan Africa" (Skjerdal: 2011) where mass communication is the title. This is different from the European titles like "media" or "communication" which are broader or show a wider understanding of media communication of journalism if the institution concentrates primarily on the journalistic craft (Skjerdal:2011:29). This also became the case for Zimbabwe with the Division of Mass Communication at the Harare Polytechnic.

Both CCOSA and the Division of Mass communication, offered certificates and diplomas in journalism awarded after studying for one year and two years respectively. Today CCOSA only offers a two and half years' diploma and have scrapped the certificate since graduands with that qualification were not marketable. The Harare Polytechnic's Division of Mass Communication is offering a two-year National diploma in either print or broadcasting journalism. According to the Division's booklet (2003) the programme is aimed at providing basic skills to students in order for them to join employment in the various media fields.

Despite these two colleges other media houses have been using cadetship to train their own reporters. The practice has been so popular with the big public organisations like The Herald and The Chronicle and later 
private institutions like The Daily News. With the cadetship scheme people are recruited and trained under the mentorship of senior personnel.

This component of training today is no longer very effective because of the lapses in the selection processes. It is more of whom you know at the media organisation and not your capability. The writer has had experience with such students, some of whom cannot construct a meaningful sentence in English but always have by-lines in their respective media houses of good stories. Some of them have already been promoted to senior reporters when their writing skills leave a lot to be desired.

From the mid 1990s the University of Zimbabwe became the first university in Zimbabwe to offer a journalism course. They introduced a post graduate diploma in Media Studies under the English department. Their student's selection was based on any first degree.

With the government still pushing its agenda of educating more black Zimbabweans more state universities were established. It became a government policy to open a state university in each of the provinces of the country. First to come was the National University of Science and technology (NUST) in Bulawayo followed by the Midlands State University in Gweru the second and third largest cities respectively. Both universities are offering media studies and journalism. ZOU was also established first to further train journalists who were already in the field but later opened up to all those who were interested in media studies.

\section{Post independence re-dress in education}

Soon after independence, the new black majority government had to immediately address the imbalances that were there in the education sector and other areas. The new government came up with policies that created an equal basis of opportunities among all Zimbabweans guided by their socialist ideology from the liberation struggle. In its 1980 education manifesto, Zanu PF pledged to have a uniform educational system, abolish the division between the African and European education as well as introduce free and compulsory primary and secondary education for all school going children regardless of race. The aim of the government was to quickly train the black Zimbabweans to take up posts which were being left vacant by the whites who were fleeing the black majority rule. Because of the critical shortage in some areas such as medicine, engineering and journalism some young blacks were sent for training in friendly countries like Nigeria and other Eastern European countries.

\section{What is Open and Distance learning (ODL)?}

Distance education (DE) is generally defined as an educational process in which the learner is separated from the instructional base or teacher either in space and/or time for a significant proportion of his learning (ADEA, 2000). Open learning, in turn, is a philosophy of learning based on the principle of flexibility to increase access and equity to education and training. It is an organized educational activity that uses a variety of media and/or teaching materials, in which "constraints on study are minimized in terms either of access, or of time and place, pace, method of study, or any combination of these" (Pieterson. 2002).

Open and distance learning (ODL) is a contemporary mode of education. Many authors have come up with a number of definitions. According to Borge Holmberg cited by Ndlovu (2002) distance education is a non-contiguous learning meaning the separation between the learner and the teacher. Today ODL is a unique world-leading education style which enables students to learn in their own time and wherever they choose.

The ZOU student's Handbook states that distance learning is a type of education where the learner is separated from the teacher by time and space unlike the conventional, face to face type.

The late Pro-Vice Chancellor of ZOU, Professor Chimedza wrote that distance education is a type of learning where for most of the time the learner and the tutor are physically separated as compared to the conventional situation where the learning uses face-to-face lectures most of the time. He said with distance education the student does most of the learning at a distance away from both the tutor and the university. In some instances such type of learning may be done at home, at work, in the fields and so on. It is a "learning process where the learner is removed in time and space from those conducting the learning" (Kamanja, 2007).

Distance education came to Zimbabweans as a blessing since many people had yearned to further their studies.

\section{Zimbabwe Open University (ZOU) - a brief history}

Zimbabweans are keen learners and this is why the country has one of the highest literacy rates in Africa. Still pushing to correct imbalances of the colonial past in education, the government realised that many working people had been gone to school up to Ordinary level and could not afford to get tertiary education. In 1993 a centre for Distance education under the University of Zimbabwe was created. It started with a slim learner population of less than one thousand Bachelor of Education students and this is how distance education started in Zimbabwe (ZOU student handbook - undated) although an almost similar concept of correspondence existed in the country for a long time. 
The Centre for Distance Education transformed into the ZOU in 1999 through an Act of Parliament. According to Prof. P. Kurasha the Vice Chancellor of ZOU, the institution was established to provide access to university education to all those who could not access it due to colonial past yet are very capable (ZOU Students Handbook). She said this is why ZOU unlike the other universities, it is not confined to one campus but is spread across all the provinces in Zimbabwe. When ZOU started its clientele were mainly working adults but today the university enrols school leavers and youths who are doing other activities to earn a leaving.

The University has a Head Office/National Centre based in Harare and ten regional offices situated the ten geo-political provincial capitals of the country as well as the eleventh region which is the virtual region catering for the international students. The Head Office is the administrative nerve centre and the regions service the students. The regional centres are responsible for the registration of students, offers orientation, consultations, face to face tutorials, runs examinations among other activities.

\section{Journalism Training at ZOU}

The journalism programme at ZOU was one of the first programmes to be introduced by the institution. The programme was designed after a realisation that the country needed better skilled and qualified people and the starting point was those already working in the media, communications and public relations fields. The first group of students was enrolled in 1999. As mentioned before, distance education and ZOU in particular was born out of a realisation that conventional forms of accessing education could not cope with the high demand for tertiary education in Zimbabwe. The majority of these people were working professionals who could not afford to leave work and family to study.

\section{Bachelor of Arts in Media Studies Structure}

The duration of the programme at ZOU eight semesters and the maximum offered is 16 semesters. The journalism programme is under the Department of Languages and Media Studies in the Faculty of Arts and Education.

The coming of journalism training by distance education provided a great opportunity for many people who had an interest in the field. The only major hindrance from the onset was the distance component. Many Zimbabweans were used to the face-to-face learning and interacting with their teachers. Many of those joining the institution had left formal education for years and with minimal computer skills (Ding, 2002).

For admission to the programme, applicants must have passed a minimum of 5 ' $\mathrm{O}$ ' levels or their equivalent including English Language. According to the ZOU General Information and Regulations Booklet (2007), applicants with either two 'A' level passes or a professional certificate or diploma approved by the University have an added advantage. There is also an exemption policy for those students who completed approved or equivalent university level courses elsewhere but shall be required to do half of their studies through ZOU.

The Bachelor of Arts in Media Studies programme is divided into four parts and each part comprises of two semesters. Each semester a student takes a minimum of four courses and a maximum of five if one has to repeat a failed course. The programme has many courses and normally not all courses listed in the regulations may be available in any one semester. From the programme's inception new courses have been crafted in response to the rapid changes in media and communication on a global scale.

For a student to proceed to the next level, a student is required to pass seven courses since they are allowed to carry only one course. At the end of the study a student must have taken a total of thirty-two courses, which translate into 128 credit points, plus a research project, which carries four credit points. The total number of credit points therefore required for someone to complete the degree is 132 .

Courses offered under this programme are set up in the following way:

Year One: The courses give an introductory element plus theoretical grounding. Here we have courses like Theories of Communication, Media and New Media Technologies and Introduction to Media in Zimbabwe and Africa.

Year Two: The courses mainly look at the interface of media and ICTs and aspects of the country's media laws and policies in conjunction with other countries.

Year Three: Students do more specialised courses plus going for attachment.

Year Four: Continuation of specialised courses and doing the research project.

\section{Assessment}

Under this programme students are required to write two assignments for every course they are doing that particular semester and sit for a three hour examination for each course at the end of the semester. To sit for the examinations students should have submitted all coursework assignments and all other registration requirements of the University (ZOU General Information and Regulations Booklet (2007). The overall weighting for the final assessment is $20 \%$ coursework and $80 \%$ written examination. 
The Zimbabwe Open University provides the printed modules as the basic learning materials and three two hour sessions per course of face to face interactions with tutors three times per semester. Computer based training materials are sometimes provided. The face to face sessions are designed in a way that during the first tutorial session, tutors give an overview of the course and guide students on how to approach the course, how to tackle assignments and the importance of forming study groups. It is during this session that new students are advised on how to use their learning material and how to write academic work.

The second tutorial session comes at the middle of the semester and tutors will have to respond to the challenges and queries raised by students. The tutors also assist students on difficult areas they are facing in the module and their studies in general. This is aimed at giving direction and feedback on areas students did not do well in their first assignments and reinforce the good areas.

During the third session at the end of the semester students and tutors polish up areas that are not clear and discuss assignments so that students use the experience as they prepare for end of semester examinations.

\section{Learner support at the Harare Region}

With reduced face-to-face interaction learner support becomes a major component in distance learning. Hall (1993) and Garand (1992) pointed out that to provide quality distance education that meets the needs of students there has to be efficient systems. The study by Belten cited by Alias and Rahman (2011) show that even rural communities in countries like Zimbabwe where a number of students are based, must be involved in coming up with necessary resources to support quality teacher-student interaction. Today other countries have developed computer-based learning systems, other technologies like audio teleconferencing and online facilities.

ZOU supports students from career prospects and study planning activities. Once the learners register with the institution during orientation they get genuine students learning needs such as advice and university regulations, procedures and study skills, academic writing and all basic necessities on distance learning.

The course materials are also designed to offer support. Having said that it is interesting to note that learner support research only concentrates on systems built to supplement the learning environment (Alias and Rahman 2011) it is ideal to look at this issue from a student's perspective. At ZOU since the introduction of the Quality Assurance directorate the focus is on induction to distance education, direction and self control, feedback and accessible resources. ZOU now has an electronic library database which is an internet based library with current books. Students are encouraged and trained how to use this facility with recent publications.

\section{Method}

According to Saba (2000) distance education research has been looked at as only the transfer of experimental method from physical to social services. As more research on education was done new methods were introduced such as self reporting by students themselves, interviewing students, surveys, discussions and discourse analysis which were seen as widening the area of data capturing generated by these various interactions between the teacher and the learner (Alias and Rahman , 2011) in both qualitative and quantitative forms.

This study used a naturalistic way to scrutinize how journalism with its practice basis of training is really taught at a distance. The model used was interactive and free of outside influence to allow the participants' answers define the nature of the findings through emergent themes.

The research was mainly questionnaire and discussion based with journalism students at the Harare Region of the Zimbabwe Open University. The journalism program was chosen because it is one of the oldest programmes in the institution. The programme has matured since inception in 1999, and this made it ideal to explore both the learner's experience and perspectives of their learning environment (Alias and Rahman 2011) taking note of key components raised.

Access to Harare Region of ZOU and students was easy since the researcher is a member of staff at the university and the regional coordinator of the programme. The researcher also talked to some part-time tutors, full time coordinators of other programmes and regions.

The participating students were selected from the seven intakes which are studying the programme since these were accessible by the researcher who was interested in the outcome. A convenience sample of all the second year to forth year students was used. This resulted in five intakes being selected. The first year students were left out so as to obtain objective results and to avoid person blaming in the responses from people who are not yet used to the system.

The five intakes had a total number of 68 students. The students were given cards with numbers from (1) one up to the last person per intake. For this study the researcher drew up a sampling frame made up of four other students and at the end of this activity 20 students were selected. This included six from intake 13, three from intake 12, two from intake 11, four from intake 10 and five from intake 9.

Their consent was also sought before the interviews and questionnaire. It was agreed that the students' identity would not be revealed and where necessary pseudonyms were used. 
From the onset, the students knew that the researcher was seeking their opinions and ideas about their learning environment as an evaluation of the current system. The questionnaires were given to each of the students. The participants were told of the time limits and the implications of the study soon after the researcher's role and objectives were highlighted. They were given two weeks to complete the questionnaire since the participants are working adults with other pressing issues to take care of. The two weeks were decided to conveniently coincide with the date the students were coming to submit their assignments and consultations so as to get maximum input. Choosing another date was impossible because with examinations also approaching it was realised that a lot of questionnaires will not be returned basing on the diversity of students in terms of location and working schedules was going to affect total collection.

The participants who took away the questionnaire were constantly kept in touch through sending them text messages on their cell phones or phoning and check on how they were preparing for examinations, problems they were facing as distance learners and how they were coping and then lead them to the questionnaire so that it was completed before coming to their examinations. According to Alias and Rahman (2011) the main challenge was to preserve the participant's interest, since one's initial excitement would disappear whilst going through the questionnaire.

Apart from the questionnaire which was given to the participating students, the interview was also used with four part-time tutors. Harare region has 18 part-time tutors and the same method used to select students was used. The interview as a practical qualitative method was used with tutors since it was thought to be the ideal method for discovering how such key people think and feel about this phenomenon under research.

The interview method with tutors was arrived at after realising that the research participant will be in front of you for an extended period of time. During the conversation, you can probe more deeply, follow up on a response and pursue a topic that you did not expect to address.

The chosen tutors were phoned to make an appointment. The interviews were carried out during our last tutorial session. This was ideal for the researcher because it became easier to access them since all were coming to the same venue for tutorials.

\section{Analysis}

The investigation was done to determine the perceptions of the learners and tutors, and not to accept that a predetermined answer to the question is known. This made the study be approached with no preconceived ideas as to how learners viewed distance learning as journalists. The researcher only took their views and experiences and did not accommodate preconceived ideas.

Originally twenty questionnaires were given out, but nineteen responded. This represented a $95 \%$ response rate. This was attributed to the constant touch with the students. In addition four interviews were carried out with individual tutors. The interview responds was $100 \%$ as all those who were interviewed managed to come and gave some response. The data collected from these interviews and questionnaires were used to determine how ZOU is teaching journalism at a distance.

\section{Results: Questionnaire}

The questionnaires showed that it was given to people who were aged between nineteen years and forty-five. The majority of the respondents came from the 21-30 age category. The demography of the students who returned the questionnaire showed that (6) six women and thirteen men participated in this study.

Table 1: Respondents by age groups

\begin{tabular}{|l|l|l|}
\hline AGE GROUP & TOTAL NUMBER & $\%$ \\
\hline $11-20$ & 4 & 21 \\
\hline $21-30$ & 9 & 47.4 \\
\hline $31-40$ & 5 & 26.3 \\
\hline $41-50$ & 1 & 5.3 \\
\hline $51-60$ & 0 & 0 \\
\hline TOTAL & 19 & $100 \%$ \\
\hline
\end{tabular}

From the selected students fifteen were practising journalists whilst four were non- practising which showed a $79 \%$ and $21 \%$ distribution respectively. From the nineteen respondents six males and four women had diplomas (53\%), two males and one female had certificates (16\%), two males had joined their organisation and later moved to the newsrooms under the cadetship scheme $(10 \%)$ and four joined the University on the basis of their secondary school qualifications (21\%).

The majority of the participants (79\%) said they joined to study by distance education because it was flexible and allows them time to do other day to day activities since they are now married. They highlighted that when they were accepted by the University they could not leave their jobs since they could afford to work 
whilst learning. The participants highlighted that they decided to study by distance as a way of furthering their studies whilst remaining at work so that they could fund their own education.

On being asked why they were doing a degree programme now those who are employed $(79 \%)$ expressed the issue of upward mobility in their various organisations where non-degreed were finding it hard to get promotion. It was pointed out by some that the system of education before where Zimbabwe had only one university has also caused many not to go for tertiary education then. When ZOU was established many decided to go for degree since the appetite for degree programmes was there and competition for jobs was increasing.

Those not employed (21\%) expressed that the situation in Zimbabwe now needed someone to have tertiary education to compete fairly on the job market and also that they failed to get places at conventional universities.

Ninety-five percent of the participants bemoaned the lack of practical sessions offered by the university. At the time of study the programme was mainly theory and the majority would have expected the university to have studios where they could do a bit of hands on experience. They expressed their wish to get practical mentoring by their tutors and said the training had too much of theory alone. Five participants who are working in the print media expressed their interest in going into either a radio or television studio so that one day they could move to the electronic media. The unemployed students were of the view that journalism as a practice based course, practicals will assist them as they seek employment.

Generally the participants were happy that distance learning had afforded them the opportunity to further their studies.

On the question of what they dislike about it, they pointed out that the system required a lot of dedication, commitment and discipline. Some even said they nearly opted out when they were failing to balance school work and work plus family issues. They gave credit to the programme coordinator and staff from the student management services for counselling and encouragement.

\section{Student needs and understanding of distance education support}

The majority of the students said they needed more proper reading materials besides the module, and that as adults with other responsibilities they lacked adequate funds to finance their studies. They greatly appreciated the way ZOU modules are written and commended that indeed they are effective journalism teachers. One student pointed out that the modules are well researched and that the in text activities guide them. For those who completed the questionnaire their learning mode is very good but they wanted more face-to-face hours to be increased from the current six hours per semester and more interaction regardless of the mode used.

With more computers and cell phones accessibility in the country many highlighted the need to keep in touch with their tutors using the gadgets. Despite the chat groups which they have been encouraged to form a few still felt they depend more on the tutor than peers since they had own study schedules.

The problem of not managing studies due to family and work commitments was brought up by mainly first and second year students. Those with serious problems were referred to the students' services department for professional counselling.

Generally the students showed resilience and strength to continue with their studies but also highlighted their need for support. Their argument was mainly based on the fact that as working adults and family people they were pressed for time. They upheld the close assignments due dates and examinations for motivating them to continue working. What really came out was that students require greater access to a variety of learning materials, learner-tutor interaction and time and logistical support.

\section{Description by participants}

Basically the participants enjoyed their learning through distance education since this enhanced their career which might have overlapped with self fulfilment (Alias and Rahman 2011). These students as adults mainly chose this mode of education because it was flexible, convenient and easy access of the learning materials. They believed that distance education was an up-to-date study skill with no yawning in the class listening to certain dry subjects by certain fatigue lecturers and that they were upbeat about their studies and promised to take head on any challenges they could face and some of them were already in their last semester (Alias and Rahman 2011). The participants show determination and resourcefulness.

The interviews with tutors mostly confirmed issues raised by students like the need for practice, extra learning materials, and the need for more face-to-face sessions with students and to put in place mechanisms which will force students to attend tutorials. The four tutors all agreed on the last issue highlighting that the students who do not attend such tutorials are easily found by the way they write their assignments and even examinations. 


\section{Conclusions and Recommendations}

From this research it was evident that students needed support and the need to sustain links with the tutors. Despite all the learning materials which can be provided by the institution like ZOU which has interactive learning materials, now internet laboratories and library information systems, the teacher still remains irreplaceable.

More research is needed on distance education in Zimbabwe since there is need to understand the experience, advantages and anxieties brought into the flexible learning environment by students using this system. A lot also has to be done to cater for student's personal and social issues. ZOU as an institution has to start to set up practical laboratories to accommodate practical oriented programmes and cater for students who are not yet working. This will give the internship part offered by conventional institutions. ZOU encourages attachments but the current crop of students mainly cannot afford to be away from their workplaces.

Although some countries are enjoying distance learning through e-learning, this remains remote in Zimbabwe. Most learners are based in rural areas and on the other hand those who are in urban areas may have limited access to new information technologies to fully embrace the potential of e-learning. Tutors have noticed that what is of interest is that most learners are still used to the conventional system of education they went through during their primary and secondary education where they were dependent of the teachers and this tendency persists through higher learning according to Ziguras (2001).

Journalism learners at ZOU expect to be "spoon-fed" and expect more direct supervision and interaction with the programme coordinator who is always available. This is also evident during the tutorials. Many part-time tutors have always complained that the students expect to be lectured and not do tutorials as per the university regulations. Instead learners are ready with their pens and paper to write what the tutor says. The learners do not want to show independence and in some instances some have stopped their studies because they feel they cannot cope with the system.

According to evaluations done every semester, ZOU students have indicated that they came ready to be taught during the tutorial sessions. They have also expressed the need to increase the number of hours for faceto-face from six hours per course per semester since they seem to benefit from tutors who bow to their pressure for lectures. This is common in many countries where distance education is still new, that learners ..."express their needs for continuous human contact and the presence of a teacher figure to guide their learning," (Alias and Rahman 2011).

It is taking time for learners to conceptualise and move from dependency and take full control of their learning through self-direction. Such a transition if it is to be sustained, there has to be a serious analysis of the learners' requirements. Learners have to get a full awareness of how the system works and then their needs later.

University was also taking long to introduce news writing and gathering module on the assumption that the majority of their students were in the field although they had started recruiting school leavers.

There is also now an urgent need for the institution to introduce computer based courses like Desk Top Publishing and other contemporary courses like Human Rights and Governance.

\section{References}

[1] N.A Alias, and N.S.N Rahman, The Supportive Distance Learning Environment: A study of the learning support needs of Malaysia online learners, 2011, Retrieved 13 March 2012 from http://www.euroll.org

[2] X. Ding, Distance higher education in the digital era, Plenary Address at the $16^{\text {th }}$ AAOU Annual Conference, Seoul, November 5-7, 2002.(unpublished)

[3] M.R. Garland, Variables affecting persistence in distance education in the natural resource sciences. University of British Columbia, Canada Doctoral Dissertation, 1992.

[4] R. Gordon, "Education policy and gender in Zimbabwe". In Gender and Education. 6 (2), 1994, 131-137.

[5] W.A. Hachten, The Training of African Joumalists. International Communication Gazette. 14(2), 1968, 101-108.

[6] R. Hall, Independent learning in practice: An examination of student behaviour in the Open University UK. Open Learning, 8(3), 1993, 2635 .

[7] F. Saba, Research in Distance Education: A status report, International Review of Research in Open and Distance Learning, 1(1), 2000.

[8] Harare Polytechnic- Division of Mass Communication booklet (2003)

[9] U. Jimada, Eurocentricmediatrainingin Nigeria: Whatalternative? Journal of Black Studies. 22 (3), 1992,366-379.

[10] L. Kamanja, Creating rich and active learning environments in Distance education. UNISA, 2007. Retrieved 24 April 2012 from http://academics.georgiasouthern.edu/

[11] M.S. Mlahleki, The post colonial state and educational policy. Harare: Centre for Distance Education ,1995.

[12] S.D. Ndlovu, Open and Distance Learning Concepts and Their Application to the Zimbabwe University Without Walls. Paper prepared for the Pan Commonwealth Forum on Open and Distance Education Durban, South Africa July 29 - August 2, 2002.

[13] C. Pieterson, Research as a learning experience: A phenomenological explication, The Qualitative Report, 7(2), 2002 . Retrieved 25 May, 2012

[14] F. Saba, Research in distance education: A status report, International Review of Research in Open and Distance Learning, 1(1), 2000.

[15] T.S Skjerdal. Teaching journalism or teaching African journalism? Experiences from foreign involvement in a journalism programme in Ethiopia. Global Media Journal African Edition, Vol 5 (1), (2011) Retrieved from www.academia.edu on 30 May 2012

[16] C. Ziguras, Educational technology in transnational higher education in South East Asia: The cultural politics of flexible learning, Educational Technology \& Society 4 (4), 2001.

[17] Zimbabwe Open University General Information and regulations Booklet. ZOU, Harare,2007.

[18] Zimbabwe Open University Students Handbook -undated 